\title{
Protocol
}

\section{Culturing Human Embryonic Stem Cells in Feeder-Free Conditions}

\author{
Sohyun L. McElroy' and Renee A. Reijo Pera \\ Center for Human Embryonic Stem Cell Research and Education, Institute for Stem Cell Biology and Regenerative Medicine, \\ Department of Obstetrics and Gynecology, Stanford University, Palo Alto, CA 94304-5542, USA
}

\section{INTRODUCTION}

Human embryonic stem cells (hESCs) have the potential to differentiate into all three germ layers and proliferate in long-term culture in vitro. hESCs can provide a cell source for the testing of novel therapies, drug screening, and functional genomics applications. Undifferentiated hESCs can be maintained and proliferated on mouse embryonic fibroblasts (MEFs) or human feeder cells. In this protocol, we describe the culture of hESCs in feeder-free conditions on Matrigel with MEF-conditioned medium. This protocol can be used for applications such as genetic modification of hESCs without feeder cell contamination.

\section{RELATED INFORMATION}

Protocols for Preparation of Mouse Fibroblast Feeder Cells for Human Embryonic Stem Cell Culture (McElroy and Reijo Pera 2008a), Culturing Human Embryonic Stem Cells with Mouse Embryonic Fibroblast Feeder Cells (McElroy and Reijo Pera 2008b), and Preparation of Human Foreskin Fibroblasts for Human Embryonic Stem Cell Culture (Panula and Reijo Pera 2008) are also available.

Images of undifferentiated hESCs growing in feeder-free conditions are shown in Figure 1.

\section{MATERIALS}

CAUTIONS AND RECIPES: Please see Appendices for appropriate handling of materials marked with $<!>$, and recipes for reagents marked with $<\mathbf{R}>$.

\section{Reagents}

All solutions should be sterilized with a $0.2-\mu \mathrm{m}$ filter and stored at $4^{\circ} \mathrm{C}$ unless otherwise specified.

$<\mathrm{R}>$ bFGF solution $(10 \mu \mathrm{g} / \mathrm{mL})$

$<\mathbf{R}>$ Collagenase solution $(1 \mathrm{mg} / \mathrm{mL})$

$<\mathbf{R}>$ Freezing medium for primary cells

$<$ R $>$ Gelatin solution $(0.1 \%, w / v)$ for MEF

hESCs (cultured in a six-well plate)

Knockout DMEM (Invitrogen 10829-018) (chilled)

$<$ R $>$ KSR medium for hESC

$<\mathrm{R}>$ Matrigel stock solution

MEF feeder cells (irradiated CF1) as prepared in Preparation of Mouse Fibroblast Feeder Cells

for Human Embryonic Stem Cell Culture (McElroy and Reijo Pera 2008a) 
$<$ R $>$ MEF medium for hESC

$<R>$ Phosphate-buffered saline (PBS) (1X) $\left(\mathrm{Ca}^{2+} / \mathrm{Mg}^{2+}\right.$-free)

Equipment

Centrifuge tubes (15-mL) (Falcon)

Dishes (tissue culture, $10-\mathrm{cm}$ ) (optional; see Step 1)

Filter $(0.2-\mu \mathrm{m})$

Incubator (humidified, $37^{\circ} \mathrm{C}, 5 \% \mathrm{CO}_{2}$ )

$<$ !>Liquid nitrogen storage tank

Microscope

Pipettes (5- or 10-mL) or cell scraper (see Step 15)

Plates (tissue culture, six-well)

\section{METHOD}

\section{Preparation of Conditioned Medium (CM)}

1. Plate irradiated MEFs at 20,000 cells $/ \mathrm{cm}^{2}$ in MEF medium as described in Culturing Human Embryonic Stem Cells with Mouse Embryonic Fibroblast Feeder Cells (McElroy and Reijo Pera $2008 \mathrm{~b}$ ), and culture overnight in a $37^{\circ} \mathrm{C}$ incubator supplied with $5 \% \mathrm{CO}_{2}$.

Use either six-well tissue culture plates or 10-cm tissue culture dishes for plating MEFs for production of conditioned medium.

2. The next day, remove the MEF medium, wash cells twice with $1 \mathrm{X}$ PBS and replace PBS with KSR medium for hESCs $\left(0.3 \mathrm{~mL} / \mathrm{cm}^{2}\right)$.

3. Collect the CM from the MEF culture dishes after $24 \mathrm{~h}$ and sterilize with a $0.2-\mu \mathrm{m}$ filter after adding an additional $4 \mathrm{ng} / \mathrm{mL}$ bFGF.

$C M$ can be stored at $-20^{\circ} \mathrm{C}$ before adding bFGF for later use.

4. Add fresh KSR medium to the MEF feeder dishes, and collect CM every day.

The irradiated MEFs can be used for up to 1 wk to produce CM.

\section{Preparation of Matrigel-Coated Plates}

5. Slowly thaw the Matrigel stock solution on ice at $4^{\circ} \mathrm{C}$ for at least $2 \mathrm{~h}$ to avoid gel formation.

6. To prepare the working solution, dilute the Matrigel stock solution 1:15 in cold knockout DMEM. Coat each well of a six-well plate with $1 \mathrm{~mL}$ of Matrigel working solution.

7. Incubate the Matrigel-coated plates for $1-2 \mathrm{~h}$ at room temperature, or overnight at $4^{\circ} \mathrm{C}$.

\section{Passaging hESCs on Matrigel-Coated Plates}

8. Aspirate the medium from the six-well tissue culture plate containing hESC colonies.

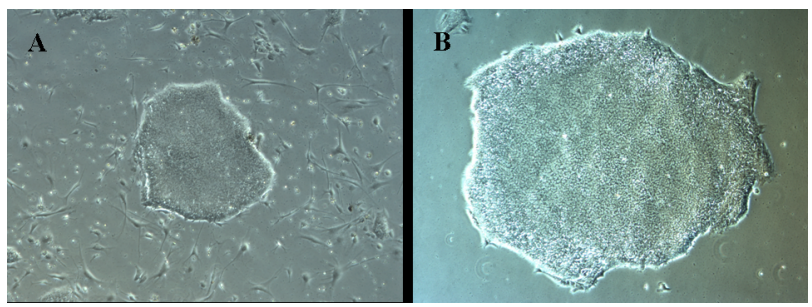

FIGURE 1. (A) A small undifferentiated hESC colony on day 1 after passage on a Matrigel-coated plate. (B) A single hESC colony ready for passage. Images were captured at 50X magnification. 
9. Wash once with $2 \mathrm{~mL}$ of $1 \mathrm{X}$ PBS $\left(\mathrm{Ca}^{2+} / \mathrm{Mg}^{2+}\right.$-free) per well.

10. Replace the PBS with $1 \mathrm{~mL}$ of collagenase solution and incubate for $10-15 \mathrm{~min}$ at $37^{\circ} \mathrm{C}$. Incubation time will vary depending on the batch of collagenase solution and the hESC lines.

11. During incubation, wash the Matrigel-coated plate twice with $1 \mathrm{X}$ PBS $\left(\mathrm{Ca}^{2+} / \mathrm{Mg}^{2+}\right.$-free), and add 2 $\mathrm{mL}$ of CM (from Step 3) per well.

12. Check the hESCs under the microscope.

Colonies should appear to have shrunken a bit, with the edges of the colonies starting to pull away from the plate, but should not be detached or floating in the medium. If the colonies have detached, collect the medium and centrifuge it to harvest the cells.

13. Remove the collagenase solution and wash twice with $1 \mathrm{X} \mathrm{PBS}\left(\mathrm{Ca}^{2+} / \mathrm{Mg}^{2+}\right.$-free).

14. Add $1 \mathrm{~mL}$ per split of $\mathrm{CM}$ (e.g., add $3 \mathrm{~mL}$ of $\mathrm{CM}$ if the cells will be split at a 1:3 ratio). We recommend a split ratio between 1:1 and 1:3, depending on ESC colony concentration.

15. Gently scrape the hESCs from the plate with a 5- or $10-\mathrm{mL}$ pipette or cell scraper into the new medium, and transfer the contents of the wells into a $15-\mathrm{mL}$ tube.

16. Dissociate the cells into small clusters (50-500 cells) by gentle pipetting. Do not reduce cells to a single cell suspension.

17. Plate $1 \mathrm{~mL}$ of $\mathrm{CM}$ containing cells into each well of the Matrigel-coated six-well plate.

18. Return the plate to the incubator. Tilt the plate several times both in the horizontal and vertical directions to spread out cell clumps evenly.

19. Feed hESCs with $2-2.5 \mathrm{~mL}$ of CM supplemented with $4 \mathrm{ng} / \mathrm{mL}$ bFGF per well every day.

20. Passage when cells are $80 \%$ confluent (see Fig. 1).

\section{REFERENCES}

McElroy, S.L. and Reijo Pera, R.A. 2008a. Preparation of mouse fibroblast feeder cells for human embryonic stem cell culture. CSH Protocols (this issue). doi: 10.1101/pdb.prot5041.

McElroy, S.L. and Reijo Pera, R.A. 2008b. Culturing human embryonic stem cells with mouse embryonic fibroblast feeder cells. CSH
Protocols (this issue). doi: 10.1101/pdb.prot5042.

Panula, S. and Reijo Pera, R.A. 2008. Preparation of human foreskin fibroblasts for human embryonic stem cell culture. CSH Protocols (this issue). doi: 10.1101/pdb.prot5043. 